Fourth International Conference on Sustainable Construction Materials and Technologies http://www.claisse.info/Proceedings.htm

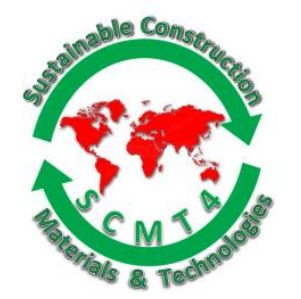

SCMT4

Las Vegas, USA, August 7-11, 2016

\title{
Strengthening of Reinforced Concrete One-Way Slabs for Flexure Using Composite Materials: Evaluation of Different Composite Materials
}

\author{
Zena R. Aljazaeri ${ }^{1}$, John J. Myers ${ }^{2}$ \\ ${ }^{1}$ Graduate Research Student, Missouri University of Science and Technology, 1304 Pine Street, 201 \\ Pine Building, Rolla, MO 65409,USA. Email: 〈zracnb@mst.edu> \\ ${ }^{2}$ Professor of Civil, Arch. and Envir. Engr, Missouri University of Science and Technology, \\ 325 Butler-Carlton CE Hall, Rolla, MO 65409, USA. ${ }^{2}$ Email: <jmyers@mst.edu>
}

\begin{abstract}
This study was conducted to evaluate the flexural performance of simply supported one-way reinforced concrete (RC) slabs strengthened using three different types of composite materials. The composites materials that used in this study were polyparaphenylene benzobisoxazole (PBO) with a cementitious-based curing agent (FRCM), carbon fiber grid with polymer curing agent (CFRP-grid), and steel reinforced polymer system (SRP). The first aim of this study was to investigate the effectiveness of these composite materials in upgrading the flexure capacity of oneway RC slab systems in terms of the load-deflection, failure mode, and displacement ductility performance. The second aim of this study was to investigate the effect of the environmental conditioning on the stiffness and flexural performance of the composites.
\end{abstract}

\section{INTRODUCTION}

There is an increasing need and a great challenge to repair and upgrade the transportation infrastructures. There can be several reasons for the need to repair and/or upgrade structures, such as a structural insufficiency due to de-icing-salts, freeze-thaw or process of deficient concrete. In other cases, a structure may have to bear larger loads in the future or in order to comply with new standards. In extreme cases, a structure may have to be repaired due to an accident or errors have been made during the design phase that the structure needs to be strengthening to achieve the design requirements (Ta“ljsten 2000; ACI440.2R2008; ACI549-4R 2013). There are several composite systems currently in use for repairing or strengthening RC structural members, which may be more or less suitable. One such composite that has been used quite extensively around the world during the last two decades is fiber reinforced polymers (FRP). That includes an epoxy agent to bond the fibers to the external surface of a structure. Despite of FRP's favorable properties, such as high strength-to-weight ratio and corrosion resistance, the epoxy resin has some limitations such as moisture permeability, poor thermal compatibility with the base concrete, poor fire resistance, and low reversibility (Ombres 2011; Babaeidarabad et al. 2014). To avoid some of these problems, various composites made of a cement-based matrix reinforced by continuous dry-fabric were 
proposed. These composites include Textile Reinforced concrete (TRC), Textile Reinforced Mortar (TRM), Fiber Reinforced Concrete (FRC), Mineral Based Composites (MBC) and Fiber Reinforced Cementitious Mortar (FRCM) (Ombres 2011). The outstanding mechanical performance of a FRCM allows this composite material to overstep the conventional carbon fiber polymers. FRCM composite with cementbased curing agent is not influenced by outdoor temperature after it hardens. It's fire-resistant is similar to the concrete base as it is an inorganic material. FRP's with epoxy curing agent not only can fail to resist fire after exceeding its glass transition temperature, but also its contribution in toxic fumes is another issue. FRCM composite can be applied on a wet surface, while FRP composite can only be applied to a dry substrate, as polyester and epoxy resins will not catalyze in the presence of water (Babaeidarabad et.al 2014; Ombres 2011). The other innovative composite system is a steel reinforced polymer (SRP). This composite has also distinguished mechanical properties that allow this composite to fulfill the structural applications such as high strength, great stiffness and excellent mechanical bond characteristic (Napoli et al. 2015; Pecce et al. 2006; Barton et al. 2005). The use of CFRP, SRP and FRCM composites in strengthening of beams and columns gained more popularity than strengthening of slabs. Limited research studies are available on strengthening and repairing of one-way reinforced concrete slabs, even though the need of their upgrade, both in buildings and in bridges, is quite common. Rahman et al. (2000) studied service and ultimate load behavior of bridge deck reinforced with CFRP grid. The ultimate-strength test showed the slab had considerable reserve capacity after undergoing at least 4,000,000 cycles of simulated design service load. The ultimate load capacity was more than five times the design wheel load. Yost et al. (2001) evaluated the flexural performance of simply supported concrete beams subjected to four-point monotonic loading and reinforced with a 2D fiber-reinforced plastic (FRP) grid. The work concluded that flexural capacity of CFRP-grid reinforced concrete beams can be accurately predicted using ACI 318-1995. Michael (2006) used carbon fiber reinforced polymer grids as confinement reinforcement for concrete. The displacement ductility of the beam utilizing the CFRP grid tubes was improved by $17 \%$ compared to the control beam with no grid tubes. Salinas (2010) used of glass, basalt, and carbon fiber girds for strengthening reinforced concrete one-way slabs. The strengthened slabs with carbon fiber grid exhibited a higher load carrying capacity and a higher displacement ductility performance before failure than the strengthened slabs with glass or basalt fibers. Ombres (2011) studied the performance of the PBO-FRCM system on strengthening reinforced concrete beams strengthened in flexure. The ultimate capacity of strengthened beams increased from $10 \%$ to $44 \%$ with respect to the value of un-strengthened beams. Babaeidarabad et al. (2014) demonstrated experimental program consists of testing $18 \mathrm{RC}$ beams strengthened in flexure with two different FRCM schemes (one and four reinforcement fabrics). Experimental results showed that the FRCM improved the flexural strength of the RC beams. Depending on the amount of FRCM, flexural capacity increased between $32 \%$ for one ply of the FRCM and $92 \%$ for four plies of the FRCM with low-strength concrete, and 13\% for one ply of the FRCM and $73 \%$ for four plies of the FRCM with high-strength concrete. Loreto (2014) discussed the performance and analysis of concrete RC slab-type elements strengthened with the FRCM. The failure mode, ultimate load, and ultimate displacement ductility were evaluated. The results showed that $40 \%$ and $100 \%$ increase in the ultimate load for one ply and four plies of the FRCM respectively. Barton et al. (2005) reported on use of externally bonded steel reinforced polymer (SRP) and steel reinforced grout (SRG) for increasing flexural, compressive, and shear capacity of reinforced concrete (RC) members. Comparisons between the analytical models and the experimental results show a good correlation for the midspan deflection until the reinforcing steel reaches the plastic region. Pecce et al. (2006) demonstrated an experimental campaign for flexural strengthening of RC beams with carbon fiber polymers and steel fiber-reinforced polymers (SRP). The results showed that the ACI 440.2R-02 approach provided conservative flexural strength. The steel cords and carbon fibers, both impregnated with epoxy gave very similar results when the reinforcement percentage was the same. For low-density steel cords bonded with cementitious grout gave a low tensionstiffening effect. Napoli et al. (2015) presented the results of 10 four-point bending tests performed on RC slabs strengthened with SRG/SRP systems. Test results provided valuable information in terms of maximum forces, deformability and failure modes by varying number of layers and density of the steel 
tape. The percentage of increase in load capacity was ranging from $40 \%$ to $90 \%$ based on the type of steel wires (low/high density), the number of layers, and the type of adhesive (epoxy/grout).

\section{RESEARCH SIGNIFICANCE}

The aim of this study was two-fold, the first aim was to study the flexure performance enhancement of oneway reinforced concrete slabs both before and after strengthening. That examined the effectiveness of three different composite systems in terms of strengthening's type and the number of strengthened layers. The second aim was to evaluate the flexure performance of the strengthened one way slabs that exposed to successive environmental cycles of freezing and thawing, high temperature and high relative humidity.

The composite systems used in this study:

1- PBO fabric with cement based curing agent (FRCM).

2- Carbon fiber grid with polymer curing agent (CFRP-grid).

3- Steel reinforced polymer (SRP).

\section{DESCRIPTION OF THE TEST PROGRAM}

\section{Specimen details and test procedure}

A total of 13 reinforced concrete slabs were fabricated using concrete in two batches. All of the slabs had a span length of $2438 \mathrm{~mm}$ (96-in.) with a rectangular cross section of $457 \mathrm{~mm}$ (18-in) wide and $152 \mathrm{~mm}$ (6-in.) deep. The average 28-day compressive strength of two batches was $38 \mathrm{MPa}(5512 \mathrm{psi})$ based on ASTM C39 at the date of beam specimens' testing. The average modulus of elasticity was 30,330 MPa (4400 ksi) based on ASTM C469. The design of the flexural steel reinforcements using Grade 60 steel was made to ensure flexural failure of the slabs (under-reinforced condition). Three coupons of reinforcement rebar were tested based on ASTM A370 (2012) to specify its tensile properties. The average yielding strength was $482 \mathrm{MPa}(70 \mathrm{ksi})$ and an average ultimate tensile strength was $726 \mathrm{MPa}(105 \mathrm{ksi})$. The slab reinforcements included four $10 \mathrm{~mm}$ (No.3) diameter bars in the longitudinal direction and $10 \mathrm{~mm}$ (No. 3) diameter bars at $305 \mathrm{~mm}$ (12-in.) spacing center to center in the transverse direction. The longitudinal and transverse section through the slab with reinforcement details are shown in figure 1.

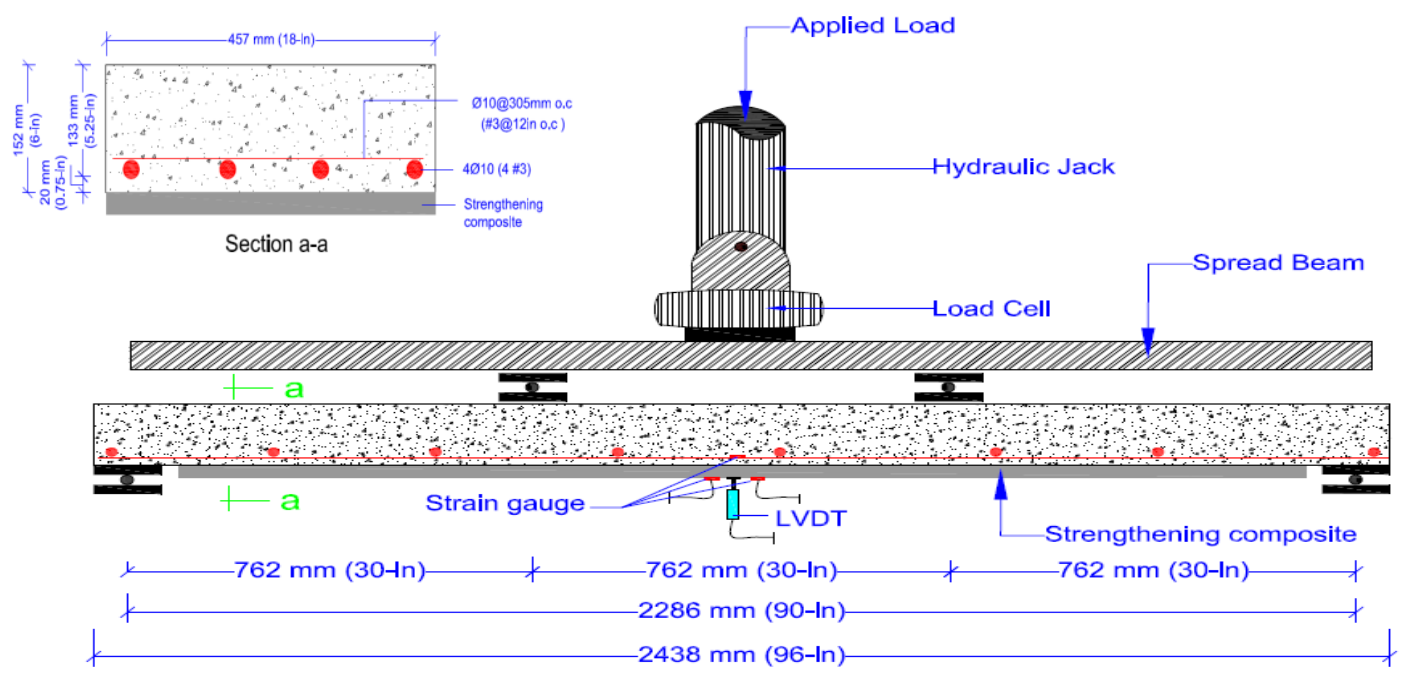

Figure 1. Cross-Section, Reinforcement Details, and Test Setup. 
The flexure test conducted on the simply supported one-way slabs loaded by two concentrated loads as shown in figure 1. The distance between supports was $2286 \mathrm{~mm}$ (90-in.) and the concentrated load was applied $762 \mathrm{~mm}$ (30-in.) from the support center. All tests were executed monotonically in a displacement control rate of $1.3 \mathrm{~mm} /$ minute $(0.05 \mathrm{in} . /$ minute).Three types of instruments were used in the tests: LVDT, strain gages, and load cells. One linear variable differential transformer (LVDT) located at mid-span was used to monitor the vertical displacement. For each slab, one strain gage was attached directly to the rebar during fabrication at the mid span location. Two strain gages were attached at the bottom surface of composite. During loading, the formation of cracks on the RC slabs sides were marked.

\section{Description, configurations and application of the strengthening composites}

Three strengthening composites were used in this study. The first composite was the polyparaphenylene benzobisoxazole (PBO) fabric mesh with cement based curing agent as shown in figure 2. PBO fabric had 5-mm (0.2-in.) width in the longitudinal direction and 3-mm (0.125-in.) width in transverse direction. The free space between the strands was approximately $5 \mathrm{~mm}(0.2 \mathrm{in}$.) and $22 \mathrm{~mm}(0.9 \mathrm{in}$.) in the longitudinal and transverse directions respectively. The nominal thickness in the two strand directions was $0.2 \mathrm{~mm}$ (0.008 -in) and $0.12 \mathrm{~mm}(0.0045-\mathrm{in})$ respectively. The tensile strength of the PBO-mesh was $5800 \mathrm{MPa}$ (840 ksi) in the longitudinal direction. The curing agent used to adhere the PBO fiber was cement based mortar (X MORTAR 750). The second composite was carbon fiber grid with polymer curing agent. The carbon grid was produced in the form of 2D strands as shown in figure 2. Each strand had a width of 6.5$\mathrm{mm}(0.25$-in.) and the grid spacing were 38 -mm (1.5-in.) and 32-mm (1.25-in.) in the longitudinal and transverse direction, respectively. The grid thickness was $1.0-\mathrm{mm}(0.04-\mathrm{in}$.) in the longitudinal direction and 2.0-mm (0.08-in.) in the transverse direction. The tensile strength of the CFRP-grid was $393 \mathrm{MPa}$ (57 $\mathrm{Ksi})$ and $496 \mathrm{MPa}(72 \mathrm{ksi}$ ) in the longitudinal and transverse directions, respectively. The curing agent used to adhere the carbon grid to the concrete substrate was Sikadur 30. Sikadur 30 is a two component structural epoxy paste adhesive with high-modulus and high-strength. The third composite was the steel reinforced polymer (SRP). It is high carbon steel cord that made by twisting five individual wires together with a micro fine brass coating. The low density steel wire with category number (3x2-4-12) was used. The steel wire's thickness was $1.2 \mathrm{~mm}(0.047$-in.) and the spacing between the steel wires was $6.4 \mathrm{~mm}(0.25$-in.).The type of low density steel wires was selected to provide equivalent strength with other types of composites used in this study. The tensile strength of the steel wire was $199 \mathrm{Mpa}(28.8 \mathrm{ksi})$. Epoxy adhesive (Sikadur 330) was the curing agent that used for bonding the steel wires to the concrete substrate.

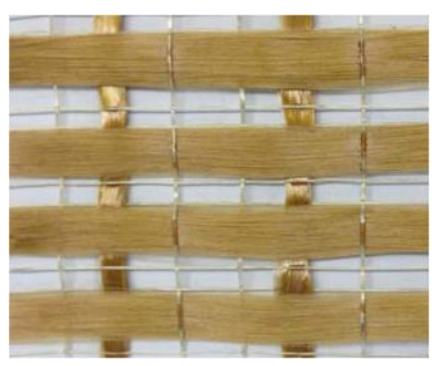

PBO Mesh

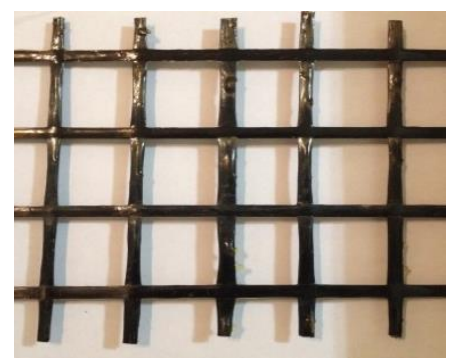

CFRP Grid

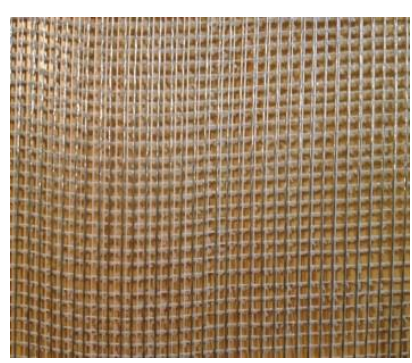

Steel Wire

Figure 2. Composites' Materials: PBO Mesh, CFRP Grid, and SR Mesh.

One RC slab served as the control slab. The other twelve slabs were strengthened with the three composites for different reinforcement's ratio. The test matrix divided into three groups based on type of composite as represented in Table 2. The first group, the slabs were strengthened by the FRCM composite. The second group were slabs strengthened by the CFRP-grid composite. The third group were slabs strengthened using a SRP composite. Each group consisted of four slabs. Three slabs were strengthened with one, two, and 
three layers of the strengthening composite, respectively. These slabs were tested under laboratory conditions. The fourth slab was strengthened with one strengthening layer and exposed to the environmental condition before testing. The maximum number of strengthening layers was based on the previous studies. That demonstrated the strengthening of RC slabs require less FRP material to achieve equivalent increases in stiffness and strength compared to RC beams (Loreto et al. 2014). In addition, ACI 440.2R (2008) and ACI 549-4R (2013) states that the flexural strength provided by strengthening reinforcements should not exceed 50 percent of the existing strength. This limit is imposed to guard against a collapse of the structure due to bond or other failure of the fiber reinforced composites that may occur in case of damage, vandalism, fire or other causes. For both FRCM and CFRP-gird composites, the sheets of the $457 \mathrm{~mm}$ (18-in.) width and $2134 \mathrm{~mm}$ (84-in.) long were cut and bonded to the tension face of the slabs in accordance with the manufacturer's specification. The SRP composite are produced in a sheet width of $305 \mathrm{~mm}$ (12-in.), which was used to lay over the tensile face of the slabs for the same length as the other composite. Then, the results were normalized for different composite's width. The identification symbol used for describing each group of test matrix was made up of three parts. The first part denoted the group number $(1,2$, and 3$)$. The second part denoted the exposure condition: $\mathrm{L}$ for laboratory conditioning and $\mathrm{E}$ for environmental exposure. The third part denoted the number of applied plies: $(0,1,2$, and 3$)$.

Table 2. Test Matrix for Strengthening Configuration and Exposure Conditions.

\begin{tabular}{|c|c|c|c|c|}
\hline Composite type & Specimen & $\begin{array}{c}\text { Layer } \\
\text { number }\end{array}$ & $\begin{array}{l}\text { Exposure } \\
\text { condition }\end{array}$ & $\begin{array}{c}\mathrm{W}_{\mathrm{f}} \text {, in./ } \\
\text { \# of strands }\end{array}$ \\
\hline Control & $\mathrm{C}-0$ & & laboratory & \\
\hline \multirow{4}{*}{ FRCM } & G1-L-1 & 1 & laboratory & 18 \\
\hline & G1-L-2 & 2 & laboratory & 18 \\
\hline & G1-L-3 & 3 & laboratory & 18 \\
\hline & G1-E-1 & 1 & environmental & 18 \\
\hline \multirow{4}{*}{ CFRP } & G2-L-1 & 1 & laboratory & 8 \\
\hline & G2-L-2 & 2 & laboratory & 8 \\
\hline & G2-L-3 & 3 & laboratory & 8 \\
\hline & G2-E-1 & 1 & environmental & 8 \\
\hline \multirow{4}{*}{ SRP } & G3-L-1 & 1 & laboratory & 12 \\
\hline & G3-L-2 & 2 & laboratory & 12 \\
\hline & G3-L-3 & 3 & laboratory & 12 \\
\hline & G1-E-1 & 1 & environmental & 12 \\
\hline
\end{tabular}

All of the slabs were precracked to an estimated $65 \%$ of its ultimate design capacity based on the ACI 440 (2008) and ACI 549 (2013) flexural capacity approach. The substrate surface of concrete was sandblasted to expose the coarse aggregate surface to achieve a perfect bond with the strengthening composite. The hand-lay method was used to apply the strengthening composites. The CFRP-grid application was executed on a dry surface by applying the mixed epoxy paste onto the concrete with a trowel or spatula to a nominal thickness of $1.5 \mathrm{~mm}(0.06$-in.).The CFRP-grid was laid and pressed into the epoxy paste until 
the paste was forced out on free spacing between the grid's strands. The grid was covered with a second layer of the epoxy paste and the surface was finished with trowel to remove excess paste. The application of the steel fiber polymer (SRP) was executed as CFRP-grid application. The FRCM application was executed on a wet surface in four steps. First step, the non- thixotropic mortar with polypropylene fibers (Exocem FP) was applied to the concrete substrate with trowel that provided a better adhesive. Second step, the first cementitious mortar layer (X MORTAR 750) was laid over for about $3 \mathrm{~mm}(0.12 \mathrm{in}$.) in thickness. Third step, The PBO mesh was applied and pressed slightly into the first mortar layer to ensure a good contact with the mortar. Finally, the second cementitious mortar layer was covered the PBO mesh and leveled to have a smooth finishing surface. The procedure was repeated for case of applying two and three layers. The CFRP-grid and SRP strengthened slabs were cured for 7 days, while the FRCM strengthened slabs required 28 days curing. The curing was maintained under the laboratory environment before any testing. The fourth slab of each group was strengthened with one composite layer and placed inside the environmental chamber as shown in figure 3. The exposure cycles included 100 cycles of freezing and thawing, 150 cycles of high temperature and 150 cycles of high relative humidity. Figure 4. Shows the changing in the temperature through the environmental regime cycles. A typical loaded oneway slab is shown in figure 5 .

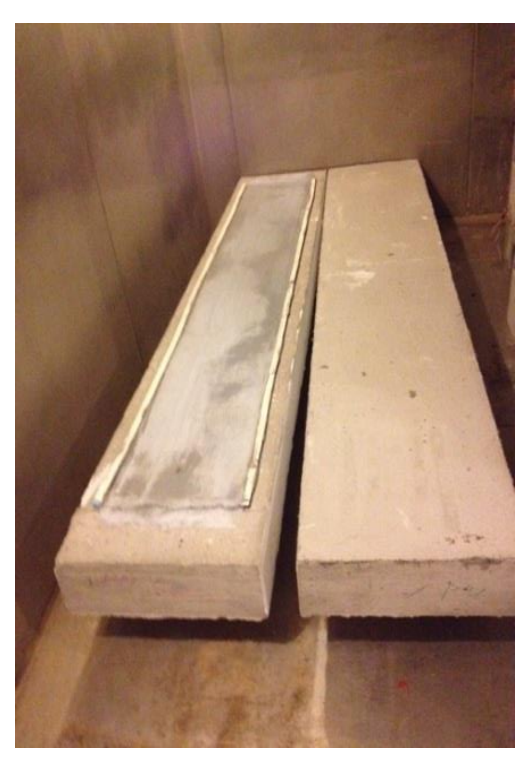

Figure 3. Inside the Chamber.

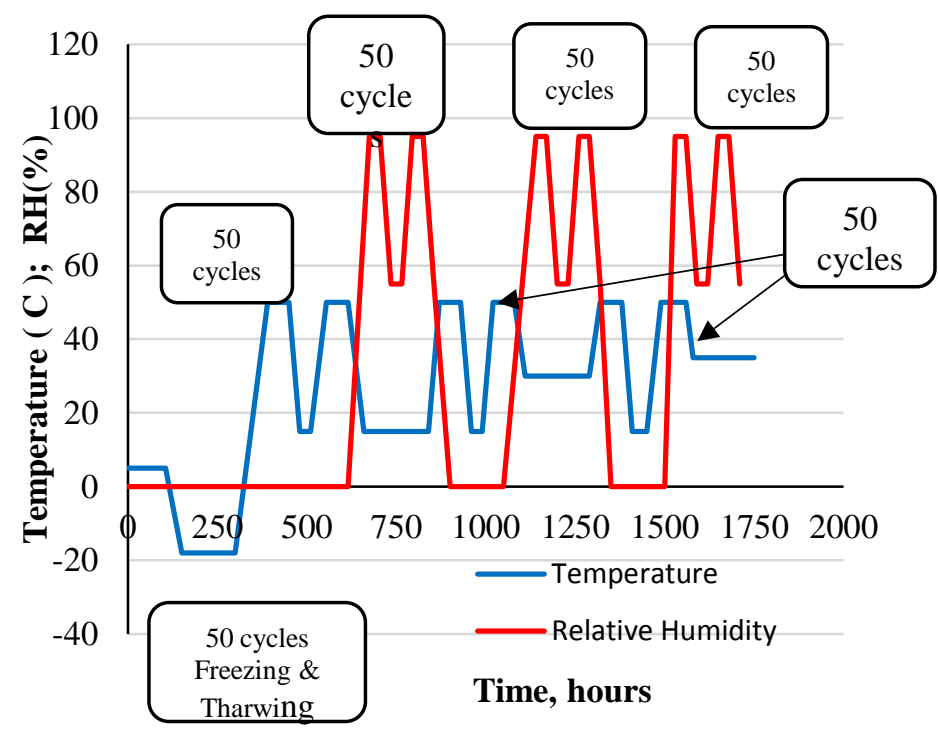

Figure. 4. Environmental Regime.

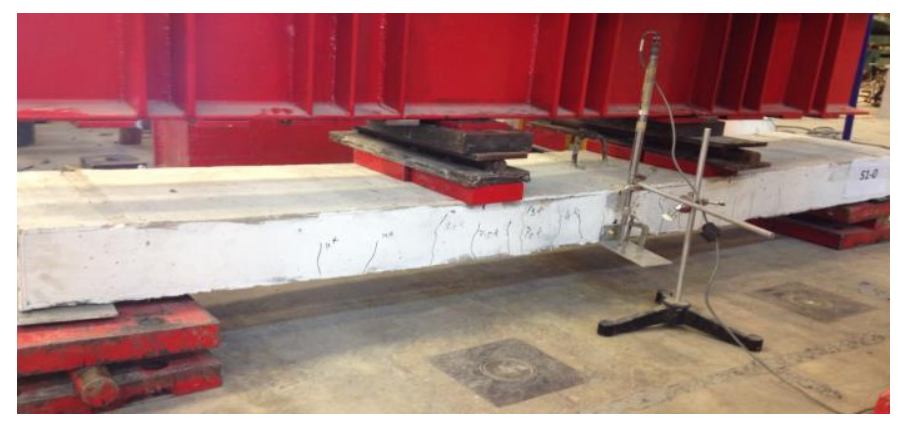

Figure. 5. Typical One Way Slab under Testing. 


\section{TEST RESULT AND DISCUSSION}

\section{Load deflection}

All of the strengthened slabs showed ultimate load higher than the control slab. The response of the all slabs was evaluated based on the load-deflection behavior. After cracking of the concrete below the neutral axis, the load versus midspan deflection was linear until yielding of tensile steel. Then, the control beam continued through the plastic deformation stage until concrete crushing was terminated the test. The strengthened slabs continued to carry loads based on the strengthening composite performance. When the strengthening composite failed, a drop in the load carrying was observed. Then, the trend of the loaddeflection curves were followed the control slab. Load-deflection curves are shown in figure 6. Figure 6a shows the load-deflection curves for the control slab and strengthened slab with one, two and three layers of the FRCM composite. Results showed that the increase in the load carrying capacity was $36 \%, 43 \%$, and $57 \%$ respectively. Figure $6 \mathrm{~b}$ shows the load-deflection curves for the control slab and strengthened slab with one, two and three layers of the CFRP-grid. Results showed that increase in the load carrying was 7\%, $36 \%$ and $43 \%$ respectively. A comparison between the strengthening composites with the layers' number is shown in figure $6 \mathrm{c}, 6 \mathrm{~d}$ and $6 \mathrm{e}$.

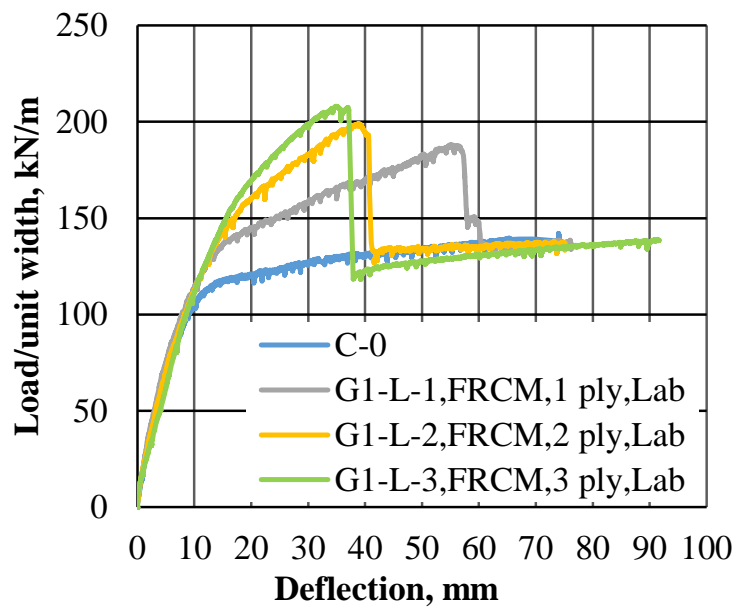

(a)

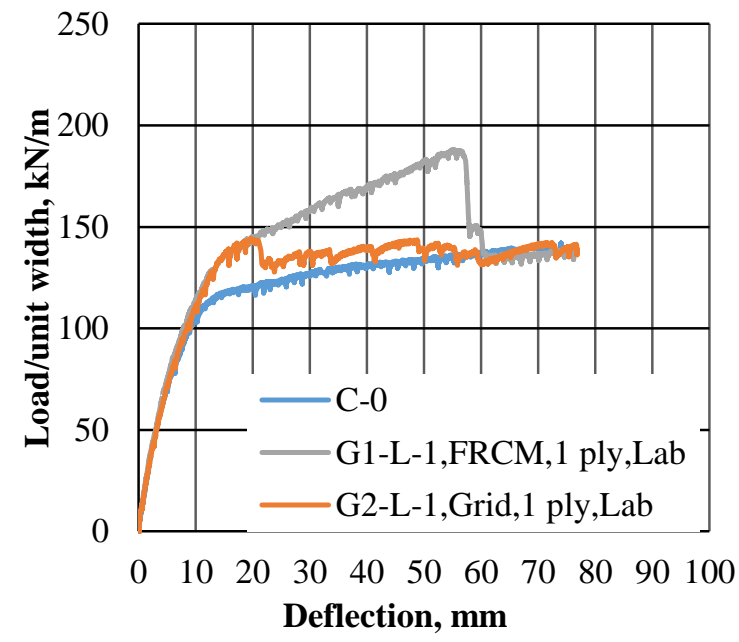

(c)

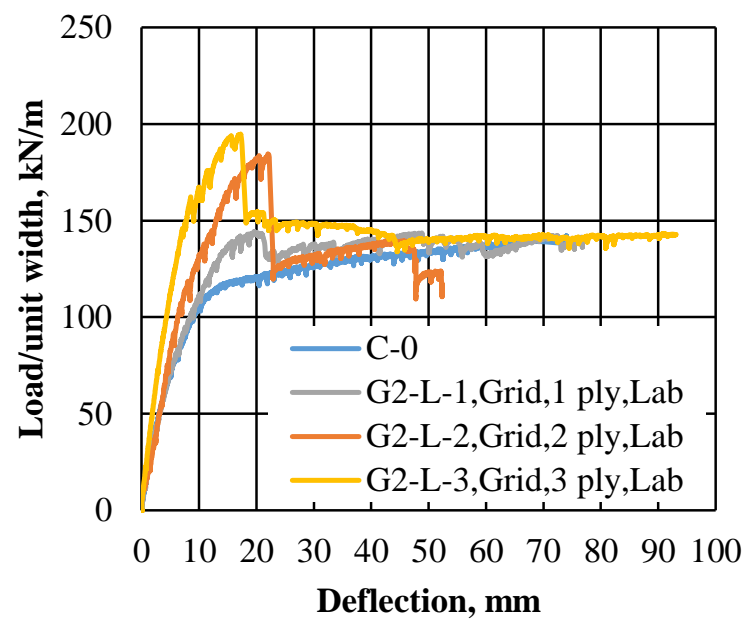

(b)

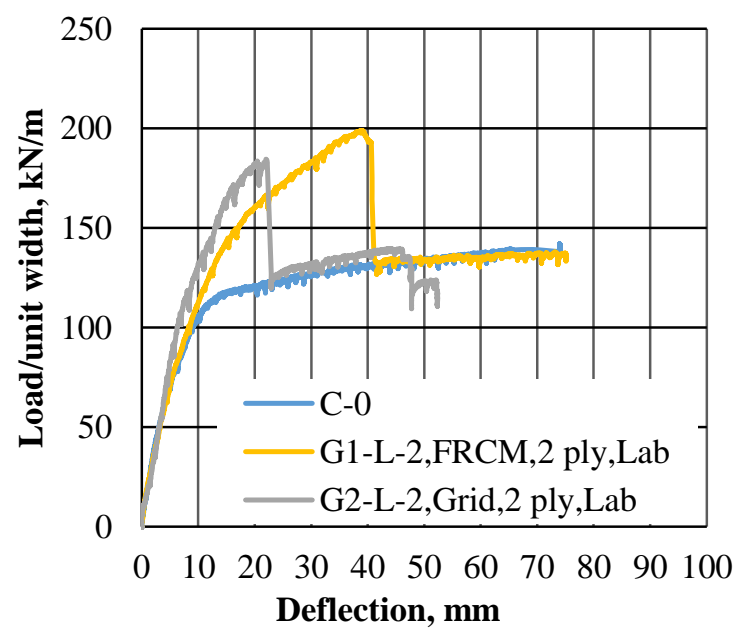

(d) 


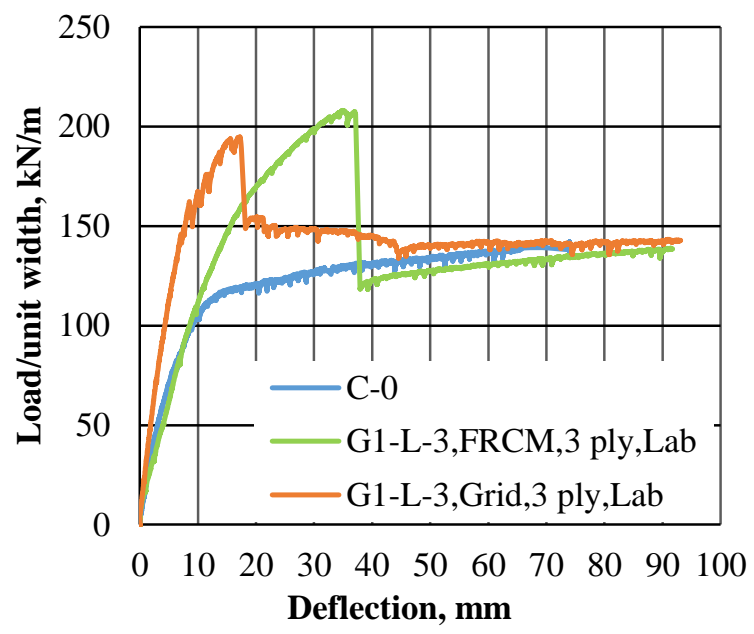

(e)

Figure 6. Load-Deflection Curves.

The strengthened slabs with FRCM composite observed better flexure performance in terms of the ultimate load and deformation ductility. However, the strengthening of slabs with two and three layers of the CFRPgrid enhanced the ultimate load as the FRCM composite, but with lower deformation ductility. This is attributed to the effective characteristics of the PBO fiber's higher tensile strength in enhancing the deformation ductility performance. The ultimate load capacity and the deformation ductility index of the tested slabs are presented in figure $7 \mathrm{a}$ and figure $7 \mathrm{~b}$, respectively. The deformation ductility index represents a representation of the area under the load-deflection curves for the control slab and the strengthened slabs.

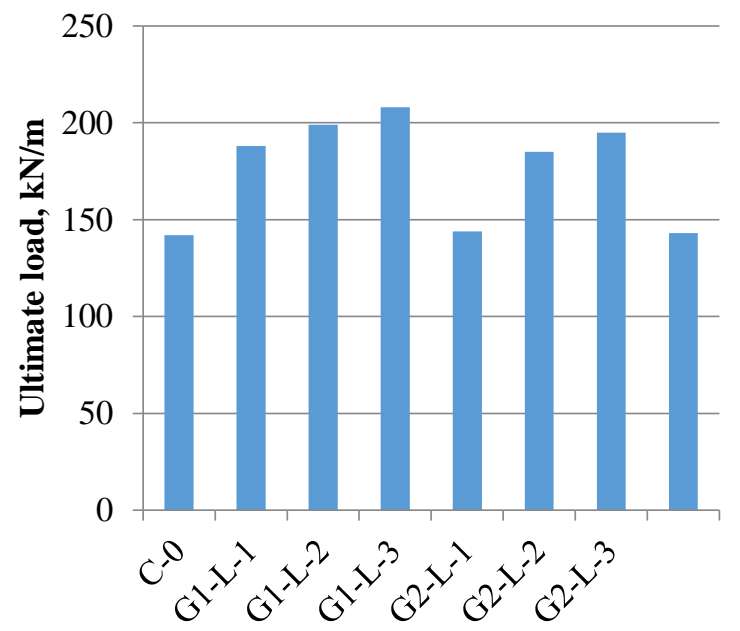

(a)

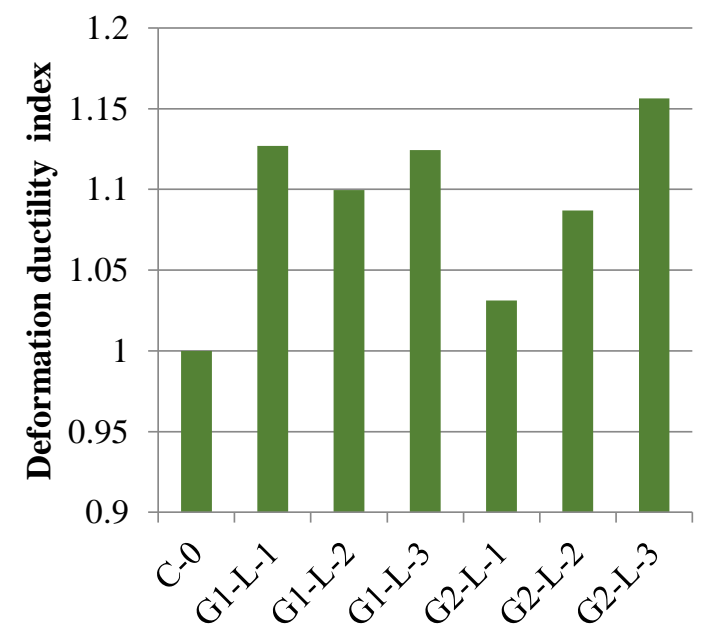

(b)

Figure 7. Ultimate Load and Deformation Ductility Index. 


\section{Failure mode}

The initial failure observed as the mild steel reinforcement yielded in the slab tension region followed by failure of the strengthening composite. The failure of the strengthening system was depended on the strengthening composite's type and the layers' number. The FRCM strengthened slabs (G1-L-1) failed by slippage of PBO-FRCM through the matrix as seen in figure 8a. The FRCM strengthened slabs (G1-L-2) and (G1-L-3) observed interfacial debonding of the PBO-fabric out of the matrix as seen in figure 8a. The CFRP-grid strengthened slabs (G2-L-1, G2-L-2 and G2-L-3) exhibited abrupt mode by rupture of the CFRP grid as seen in figure $8 b$.
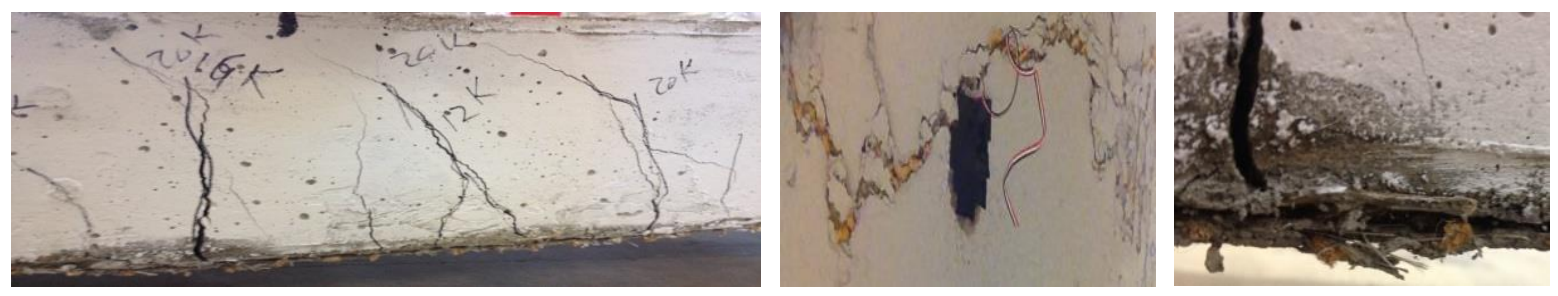

\section{Typical Crack Pattern Slippage Failure Debonding Failure}

a) FRCM Strengthening Composite.
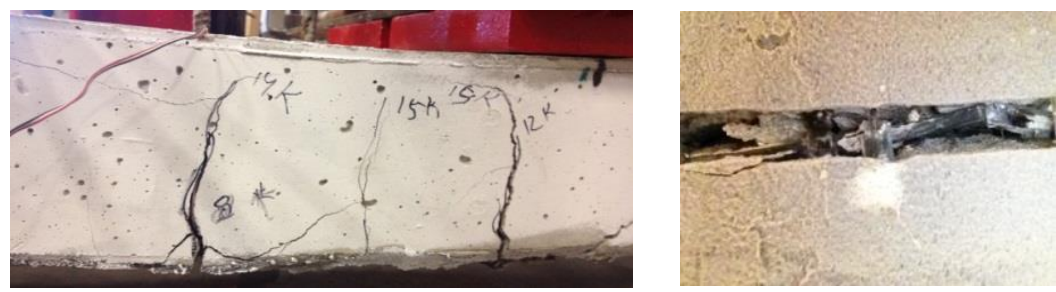

Typical Crack Pattern CFRP-Grid Rupture

b) CFRP-Grid Strengthening Composite.

Figure 8. Crack Pattern and Failure Mode of Strengthened RC Slabs.

\section{CONCLUSION}

Externally bonded FRCM composite or carbon grid polymers have demonstrated to be very effective in enhancing the flexure capacity of one-way RC slab systems. A higher increase in the load carrying capacity and the deformation ductility observed for the slabs strengthened with FRCM composite versus strengthening with a carbon grid composite system. The ultimate load increased with increasing the number of the composite layers. The failure mode of all strengthened slabs started by yielding of the internal mild steel reinforcement followed by slippage or debondng of the FRCM composite and partial rupture of CFRP grid at the location of the maximum deflection.

Work is undergoing for strengthening and testing the other slabs. In the next phase of investigation the effect of environmental exposure, deformation performance, effectiveness in the number of strengthened layers, failure modes \& effect of strengthening type will be investigated.

\section{ACKNOWLEDGMENTS}

The authors gratefully acknowledge the financial support provided by the Ruredil Company, the ReCAST Tier 1 University Transportation Center at Missouri S\&T as well as the support from the Center for Infrastructure Engineering Studies and the Department of Civil, Architectural and Environmental Engineering at Missouri S\&T. 


\section{REFERENCES}

ACI (American Concrete Institute). (2008). "Guide for the design and construction of externally bonded FRP systems for strengthening concrete structures.” ACI 440, Farmington Hills, MI.

ACI (American Concrete Institute). (2013). "Guide to design and construction of externally bonded fabricreinforced cementitious matrix (FRCM) systems for repair and strengthening concrete and masonry structures," ACI 549, Farmington Hills, MI.

ASTM C39 (2014). "Standard test method for compressive strength of cylindrical concrete specimens," West Conshohocken, PA.

ASTM C109 (2013). "Standard test method for compressive strength of hydraulic cement mortars (using 2-in. or [50-mm] cube specimens)." West Conshohocken, PA.

ASTM C469 (2014). "Standard test method for static modulus of elasticity and poisson's ratio of concrete in compression." West Conshohocken, PA.

ASTM A370 (2012a). "Standard test methods and definitions for mechanical testing of steel products." West Conshohocken, PA.

Babaeidarabad, S. Loret, G. and Nanni, A. (2014). "Flexural strengthening of RC beams with an externally bonded fabric-reinforced cementitious matrix." Journal of Composites for Construction, 10.1061/ (ASCE) CC.1943-5614.0000473, 0401400.

Barton, B., Wobbe, E., Dharani, L.R., Silva, P., Birman, V., Nanni A., Alkhrdaji, T., Thomas, J., Tunis, G., (2005), " Characterization of reinforced concrete beams strengthened by steel reinforced polymer and grout (SRP and SRG) composites,' Materials Science and Engineering, A 412, 129-136.

Loreto, G., Leardini, L., Arboleda, D. and Nanni, A. (2014). "Performance of RC slab-type elements strengthened with fabric-reinforced cementitious-matrix composites." Journal of Composites for Construction, 10.1061/ (ASCE) CC.1943-5614.0000415, A4013003-1.

Michael, A.P., (2006)," Using carbon fiber reinforced polymer grids as confinement reinforcement for Concrete," Ph.D. Dissertation, University of Florida, Gainesville, FL, US.

Napoli, A., and Realfonzo, R. (2015)." Reinforced concrete beams strengthened with SRP/SRG systems: Experimental investigation,' Construction and Building Materials, 93, 654-677.

Ombres, L. (2011). "Flexural analysis of reinforced concrete beams strengthened with cement based high strength composite material." Composite Structures, 94(1), 143-155.

Pecce, M., Ceroni, F., Prota, A., Gaetano Manfredi, G., (2006).' Response prediction of RC beams externally bonded with steel-reinforced polymers," Journal of Composites for Construction, DOI: 10.1061/ (ASCE) 1090-0268(2006)10:3(195).

Rahman, A. H., Kingsley, C. Y., and Kobayashi, K. (2000).' Service and ultimate load behavior of bridge deck reinforced with carbon FRP grid,' Journal of Composites for Construction, 4(1), ISSN 1090 0268/00/0001-0016-0023.

Ruredil Company for construction chemicals and building technology, Italy.

Salinas, A.J.O., (2010). "Use of grancrete as adhesive for strengthening reinforced concrete structures," Thesis, North Carolina State University, Raleigh, NC, US.

Ta"ljsten, B., and Elfgren, L. (2000). "Strengthening concrete beams for shear using CFRP-materials: evaluation of different application methods,' Composites, Part B, 31, 87-96. 
Yost, J.R., Charles H. Goodspeed, C.H., and Schmeckpeper, E. R. (2001). Flexural performance of concrete beams reinforced with FRP grids,' Journal of Composites for Construction, 5(1), ISSN 10900268/01/0001-0018-0025. 